\section{気仙沼湾の砂浪}

茂木昭夫

チリ地震㨁後の1960年6月6日，津波の被害 の大きかった三陸諸港湾の調査に赴いた際, 筆 者は気似沼湾に顕著な砂浪の発達のある事を知 った。音響測深の記録に三角波の形で特徵的に あらわれ，底質調查によって，これらが砂の波で ある事が確認されたのである。チリ地震津波に よって気仙沼湾の蜂尔崎水道は, 最大約 $10 \mathrm{~m}$ 洗 掘され, 狭水路を作っている導流堤の北半部は, 完全に破瓖されて導流堤を横切る深い溝が形成 された (Kawamura, B. and Mogi, A. 1960)。 砂浪はこの侵蝕部に形成されている。津波を受 ける前の状態を示す音測記録がないので津波の 前後に扣ける砂浪の比較はできないが，現在の 砂浪が津浪によって著しく侵蝕された部分に形 成されている事から，この時の侵蝕作用によっ て形成されたものである事は確かである。気仙 沼湾の地形を見ると，中央部の蜂方崎付近辺で 狭く両側に開いているが，導流堤によってこの 部分は更に狭まり，かつ蛇行している。これは 航路の水深を常に維持する為になされたもので あるが，津波に遭遇してこの平衡は破れ，蛇曲 による遠心力が流量执よび流速の増大に伴って 異常な強さの副流を発生し，この副流によって この部分を著しく洗掘して, 現在の $10 \mathrm{~m}$ 以上の

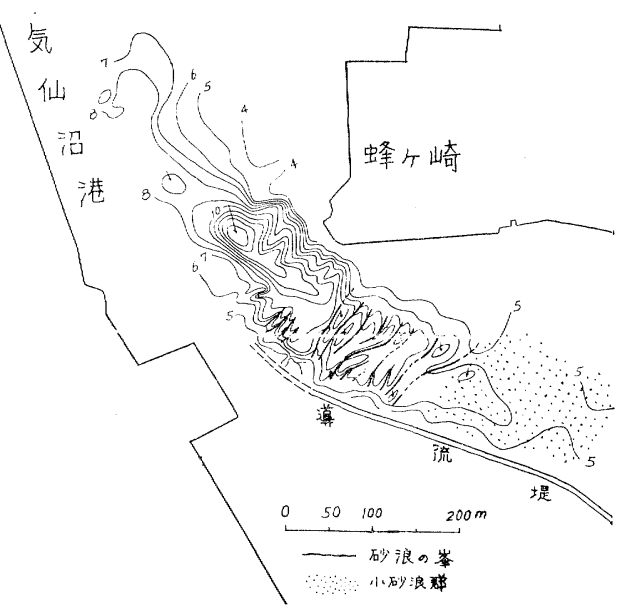

釜状の深みを形成している。砂浪はこの深みか ら, その南東部の水深約 $4 \mathrm{~m}$ の浅堆部にかけて 存在し, 砂浪の峯の方向はこの航路筋 (流心) に 対乙直角方向で，かつ平行に配列する。砂浪の 大きさ深みの周辺で大きく波高 $0.5 \sim 1.5 \mathrm{~m}$. 波長 10〜20m を示すが, 南東の浅瀬に移ると急 に大きさを減じ波高 $0.5 \mathrm{~m}$ 以下・波長 $5 \mathrm{~m}$ 以下を 示寸に至る。更にこの浅瀬加南方に向って次 第に深くなるが，ここでは砂浪は全然存在しな い。底質を見ると深み付近は細䃋を混光た粗砂 であるが，南の方に漸次細粒となり，水深 $4 \mathrm{~m}$ の浅堆では中砂を示しここから南に深くなると 泥に変る。すなわち砂浪は備讃瀬戸（茂木・加 藤 1962）に扣いて見られた場合と同様, 細礫・ 砂の底質の所にのみ存在している。この砂浪の 形成を津波本流の直接の所産と見る事にはいさ さか疑いをるつに至った。むしろ蜂ケ崎水道部 の洗掘と同じ様に副流（潜流）の影響を重視し たい。すなわち狭水道部においては，蛇曲によ る遠心力により，西岸に执いて下にもぐる流れ が生じ，海底では流心とは直角方向に西岸から 東岸に向う流れが生じたと考えられる。津波の 際の洗掘はすなわちこの潜流によるものである が, 砂浪の峯の方向がこの流れに平行して扔り， 砂浪の最も顕著な部分が両岸斜面に存在してい る事は，この考完に有利であると考兄られる。 同じ様な傾向は備讃瀬戸においても存在し, 砂 州の斜面部に斜面を流下する方向の峯をもった 砂浪が多く発見されているのである。砂浪のそ の後の消息は 1 つの関心事であり, 調査後 1 年 を経た 1961 年に再び蜂厅崎水道を調査したが， 依然として存在しており，大きな変化を示して いなかった。今後も機会ある毎に観測したいと 思っている。

(1965.8.15 受理)

Kawamura, B and Mogi, A(1961): On the Deformation of the sea bottom in some harbours in the Sanriku coast due to the Chili Tsunami Report on the Chilean Tsunami of May 24, $1960 \quad 57 \sim 66$

茂木昭夫, 加藤俊雄 (1962)：備讃瀬戸東部の sand waveについて 海洋地質 $12 \sim 12$

\title{
Sand Waves in Kesennuma Harbour
}

\begin{abstract}
Akio MOGI
Kesennuma harbour suffered a great damage caused by the Chilean. Tsunami of May 24, 1960. Erosion caused by the Tsunami in this harbour was remarkable at the narrow waterway near Hatigasaki in particular. There are sand waves aligning transverse to the direction of the narrow water-way in the eroded area, according to the results of detailed survey which was made just after the Tsunami. The length of sand wave near Hatigasaki attained 20 meters, and amplitudes 1.5 meters. The group on the shallow sea bottom to the southeast of Hachigasaki was less than 5 meters in length and 0.5 meters in amplitude. It is likely that the sand waves were formed by the secondary current of the Tsunami which flowed west to east near bottom and were caused by the curvature of the narrow water-way.
\end{abstract}

